\title{
Waste Management in Propylene Epoxidation Process with the Use of Supercritical Fluid Media*
}

\author{
F. M. Gumerov, R. A. Kayumov, R. A. Usmanov, A. A. Sagdeev, I. Sh. Abdullin, R. F. Sharafeev \\ Nizhnekamsk Institute of Chemical Technology (Branch), \\ State Educational Institution, Kazan National Research Technological University, Kazan, Russia \\ Email: gum@kstu.ru
}

Received October 23, 2012; revised November 25, 2012; accepted December 7, 2012

\begin{abstract}
Experimental results on solubility of the styrene, phenol, methylphenylcarbinol, acetophenone, ethyl benzene, propylene glycol and molybdenum as a complex with Trilon $\mathrm{B}$ in supercritical $\mathrm{CO}_{2}$ obtained using a dynamic (flow) method are presented. The obtained data are described in the framework of Peng-Robinson equation. The results of the experiments on the extraction of organic components from waste formed in the olefin epoxidation process at Nizhnekamskneftekhim Inc., on the analysis of extract composition, and on the testing of the extract as an epoxidation catalyst are presented. The supercritical water oxidation (SCWO) process of epoxidation process waste was conducted in periodical and continuous mode. The analysis results of reaction product are given. Pilot experiments on dry sediment formation were conducted using Radio Frequency (RF) Inductively Coupled Plasma (ICP) of low pressure.
\end{abstract}

Keywords: Styrene; Phenol; Methylphenylcarbinol; Acetophenone; Ethyl Benzene; Propylene Glycol; Molybdenum; Supercritical Carbon Dioxide; Solubility; Dynamic Method; Description of Solubility; Peng-Robinson Equation; Supercritical Water Oxidation; High-Frequency Induction Plasma

\section{Introduction}

The subject of this study is to shift the epoxidation process, realized at JSC "Nizhnekamskneftekhim". Feature of this process is to use the form of metal complexes of molybdenum (Molybdenum Catalyst Complex-MCC) in the liquid phase as a catalyst. During the processing and separation of the reaction mixture the molybdenum salts, formed by the destruction of the MCC, are concentrated in the effluent (48 tons of Molybdenum are used per annum, $90 \%$ of which are thermal combustion). Runoff composition is as follows:

- Ethyl benzene, $\mathrm{C}_{6} \mathrm{H}_{5} \mathrm{CH}_{2} \mathrm{CH}_{3}-2.5 \%$ by weight;

- Acetophenone (ACF) $\mathrm{CH}_{3} \mathrm{COC}_{6} \mathrm{H}_{5}-1 \%$ by weight;

- Methylphenylcarbinol (MPC) $\mathrm{C}_{6} \mathrm{H}_{5} \mathrm{CH}(\mathrm{OH}) \mathrm{CH}_{3}-$ $6.5 \%$ by weight;

- Phenol, $\mathrm{C}_{6} \mathrm{H}_{5} \mathrm{OH}-2.5 \%$ by weight;

Of combinations of processes that solve the problem of removing or exclude the presence of hydrocarbons and molybdenum (in some form) in the water flow. The first option is based on the use of supercritical fluid extraction process with respect to both target components flow. In the second option the implementation of the water source runoff supercritical water oxidation (SCWO) process is

*Authors are grateful to Russian fundamental researches fund (project \#11-08-12090-ОФИ-М-2012). expected with associated sedimentation of molybdenum in the composition of the inorganic sediment and its subsequent concentration using RF ICP of low pressure. Finally, the third option it is a combined process of supercritical fluid extraction of hydrocarbons and the process of supercritical water oxidation with subsequent sedimentation of molybdenum in the SCWO process and concentrating in ICP. The optimality of one of the options can be set through the study of the feasibility and characteristics of processes above, and as a result of the outcome of the comparative economic analysis.

This study considers two options of a s-Propylene $\mathrm{C}_{3} \mathrm{H}_{8} \mathrm{O}_{2}-12 \%$ by weight;

- Molybdenum $\mathrm{Mo}-0.2 \%$ by weight;

- Water $\mathrm{H}_{2} \mathrm{O}-40 \%$ by weight (on Fischer);

- Other-35.3\% by weight.

Disposal of this waste is an important task, because the components are of great value for the chemical industry as a raw material, and molybdenum is attractive as the active ingredient in the catalyst and other areas of the economy.

To solve the problem of molybdenum and hydrocarbons extraction, which are raw materials for the petrochemical industry, this study considers the possibility of supercritical fluid technologies and RF ICP of low pressure. In this case there are at least three options olution. 
Feasibility and effectiveness of supercritical fluid extraction process, expected to be used as a part of allocation task of both components from industrial waste, primarily determined by the last acceptable solubility in the appropriate extractant (pure or modified $\mathrm{SC}-\mathrm{CO}_{2}$ ). This actually determines the priority objectives of the solubility of waste components studies that had not studied yet and setting the optimal ranges of operating parameters in the extraction process. Complex wastes composition determines the need of oxidation process implementation and study in supercritical water media, as well as the molybdenum salt deposition kinetics.

\section{The Experimental Part}

\subsection{Supercritical Extraction}

To investigate the solubility of the waste components a supercritical fluid extraction setup was used.

The setup (see Figure 1) is mounted on the base of liquid piston pump 3. Liquid-phase state of the extractant in the feed of pump 3 is provided by pumping a chilled water $(\mathrm{T}=278 \mathrm{~K})$ via low-temperature heat exchanger 2 (capacity of $25 \mathrm{ml}$ ) and the pump cylinders cooling case 3. Consumption sets by a pump control panel up to 0.01 $\mathrm{ml} / \mathrm{min}$, the system pressure is controlled by two pressure gauges (at the output of the pump and the pump cell).

The extraction cell 4 is placed in a thermostatic bath 9 . Temperature accuracy is $\pm 1 \mathrm{C}$. Extractant collector 6 is provided with an extract throttling device 5, which allows releasing pressure of supercritical solution to the atomspheric value. Gas consumption after the extract collection is measured by the gas flow meter 7. Solubility determination was conducted by a dynamic method. Before serving the solvent, the cell is filled with the test substance and sealed. Then it is temperature-controlled for $20 \mathrm{mi}-$ nutes. The solvent feeding to the extraction cell is preheated in a coil to minimize thermal gradients.

1) Cylinder with carbon dioxide; 2) Low-temperature heat exchanger; 3) Plunger pump; 4) Cell extraction; 5) Expansion device; 6) A collection of extracts; 7) Gas flow

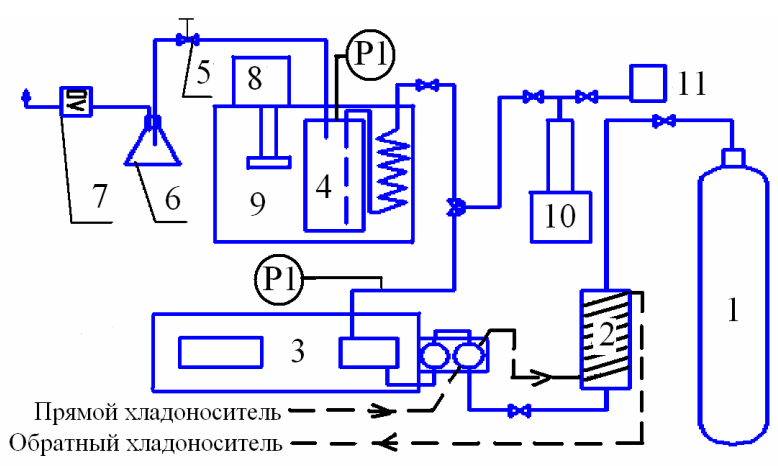

Figure 1. Experimental setup. meter; 8) Heater; 9) Thermostatic bath; 10) Pump cosolvent; 11) Tank co-solvent.

Reagents with the content of the basic substance of at least $98 \%$ were used in the experiment.

To eliminate the effect of the errors related to obtaining non-equilibrium concentration of the supercritical solution, experiments were conducted to determine the dependence of SCF solvent consumption and measuring cell filling degree on objective component concentration. There is a graph in Figure 2 which shows the dependence of MPC concentration on the solvent consumption: I- equilibrium concentration zone, II-nonequilibrium concentration zone. Similar relationships were obtained for the ACF, propylene and ethyl benzene.

As it can be seen in the graph, with the increase rate of the solvent, from some of its value, the concentration of the substance in the solution is reduced (nonequilibrium concentration zone II). To obtain reliable results in line with the concept of the "solubility", solvent consumption in the main experiments was selected from the values corresponding to the area $\mathrm{I}$.

An important factor in obtaining reliable data on the solubility is the cell filling level with the test substance. For this reason, the measurement procedure of the main components of solubility in supercritical $\mathrm{CO}_{2}$ was preceded by the study of the concentration of carbon dioxide in the matter of the degree of filling a wet-cell with test substance. Immutability concentrations (zone II), corresponding to a certain range of the filling, were the basis for acceptance of the equilibrium concentration or desired solubility. Figure 3 shows the dependence of the $\mathrm{ACF}$ in $\mathrm{SC}-\mathrm{CO}_{2}$ from the fill volume of the cell at different thermodynamic parameters in this range of solvent consumption $(\overline{\mathrm{V}})$, where conditionally designated the following areas: I-nonequilibrium concentration zone, II—zone responsible for solubility concept, III-drip ablation zone.

Similar graphs were obtained for all components of the water flow at temperatures of 318,323 and $328 \mathrm{~K}$. It should be noted that the concentration of propylene glycol in $\mathrm{SC}-\mathrm{CO}_{2}$ was unchanged in the range of cell filling from $30 \%$ to $70 \%$.

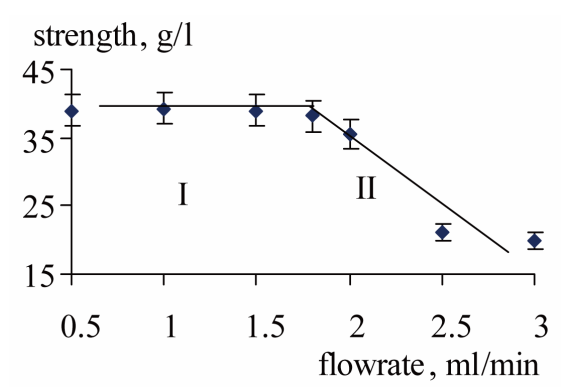

Figure 2. Dependence of the IFC in SC- $\mathrm{CO}_{2}$ on solvent consumption at $P=15 \mathrm{MPa}$ and $\mathrm{T}=323 \mathrm{~K}$. 


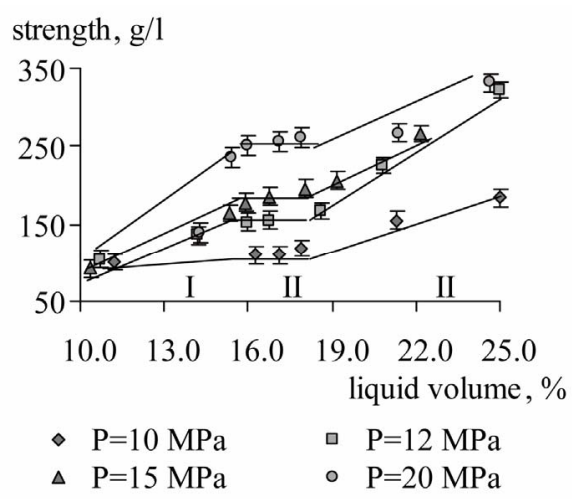

Figure 3. The dependence of the Acetophenone concentration in SC-CO $\mathrm{C}_{2}$ and cell filling value at $\mathrm{T}=318 \mathrm{~K}$.

\subsection{Supercritical Water Oxidation}

For the supercritical water oxidation process the experimental setup was used (Figure 4), which is a high-pressure cell with $32 \mathrm{ml}$ placed in a heating furnace. Medium temperature in the cell and the pressure were measured by temperature and pressure sensors. This experimental setup allows us to implement the process of industrial waste water SCWO in a static mode in the pressure range from $23 \mathrm{MPa}$ to $60 \mathrm{MPa}$, temperatures up to $800 \mathrm{~K}$. SCWO process was made on $20 \%$ aqueous waste. $30 \%$ hydrogen peroxide $\mathrm{H} 2 \mathrm{O} 2$ was used as an oxidizer.

1) High-pressure cell, 2) Heating furnace, 3) Thermocouple hot junction, 4) Tube pressure gauge, 5) Pressure PD100-DI, 6,7,11) Secondary devices TRM-101 for pressure and temperature, 8) Electric, 9) Stand oven, 10) Insulation.

For the supercritical water oxidation process the experimental setup was used (Figure 4), which is a highpressure cell with $32 \mathrm{ml}$ placed in a heating furnace. Medium temperature in the cell and the pressure were measured by temperature and pressure sensors. This experimental setup allows us to implement the process of industrial waste water SCWO in a static mode in the pressure range from $23 \mathrm{MPa}$ to $60 \mathrm{MPa}$, temperatures up to $800 \mathrm{~K}$. SCWO process was made on $20 \%$ aqueous waste. $30 \%$ peroxide $\mathrm{H}_{2} \mathrm{O}_{2}$ was used as an oxidizer.

Industrial wastewater SCWO process conducted under continuous mode.

An experimental setup for wastewater SCWO process in continuous mode was invented by the authors.

The setup (Figure 5) consists of the following parts:

- Tubular reactor

- Charging system

- Temperature maintenance system

- The system of sampling and filtering

1) Container for mixing the oxidizer effluent, 2) High pressure pump, 3) Reactor, 4) Filter solids, 5) Condenser, 6) Gas-liquid separator, 7) A collection of liquid product.

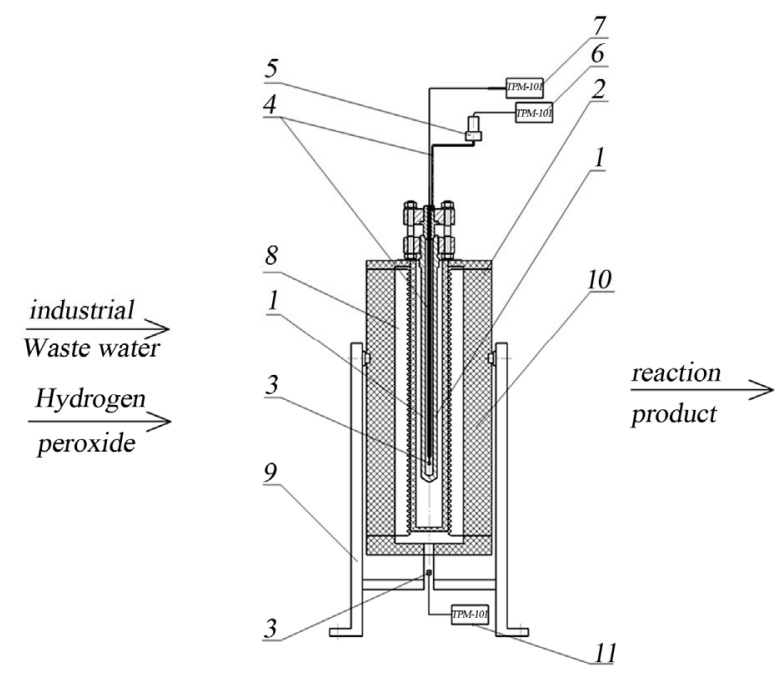

Figure 4. SCWO experimental setup.

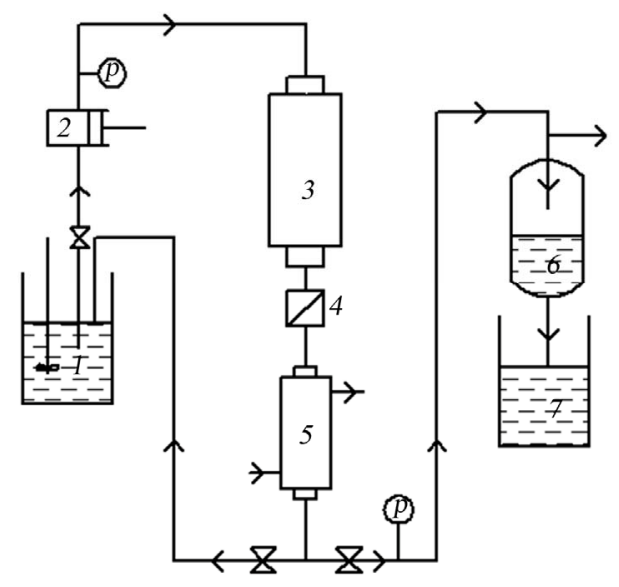

Figure 5. SCWO running pilot setup.

The test experiments were conducted on the setup in the temperature range of $673-893 \mathrm{~K}$ and pressures of 180 - 300 bar. "Nizhnekamskneftekhim" wastes oxidation was conducted with $20 \%$ concentration, $30 \%$ hydrogen peroxide $\mathrm{H}_{2} \mathrm{O}_{2}$ was used as the oxidant, the volume ratio of waste to solvent 1:2.

\subsection{Concentration of Molybdenum Using ICP}

RF plasma generator allows the implementing power supply without any electrodes. This provides high purity of generated plasma and long life cycle of the plasma reactors. These qualities define the benefits of RF plasma versus the other types of plasma discharges used in industrial processes, for which the purity of the plasma is a critical factor in obtaining new materials [5-7].

RF ICP setup used in the study consists of standard blocks and elements (Figure 6): the RF generator, an inductor, a vacuum system, plasma gas supply systems and diagnostic equipment. Argon was used as a plasma 


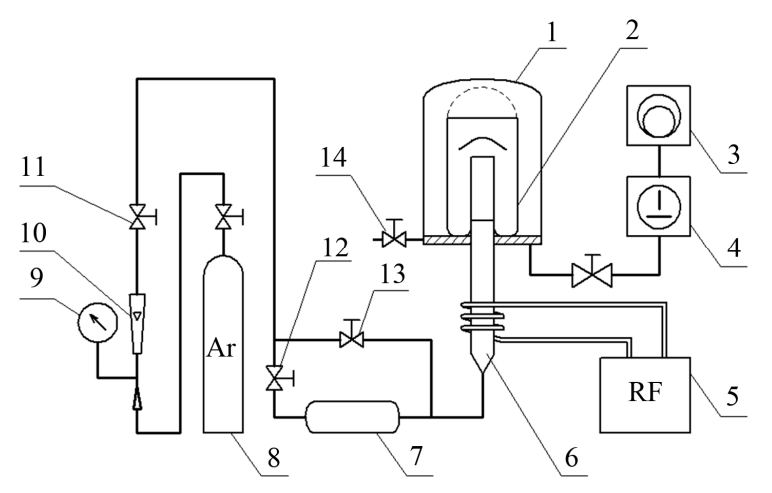

Figure 6. Supply of a powder material by pneumatics in the ICP of low pressure.

gas. The range of flow rate from 0 to 0.2 gr./s. The oscillator (generator) frequency is $1.76 \mathrm{MHz}$. Power in the discharge varies from 0.5 to $2.5 \mathrm{~kW}$, the pressure from 13 to $133 \mathrm{~Pa}$ [8].

1-vacuum chamber; 2-entrap glass; 3-sliding vane rotary pump; 4-twin-rotor vacuum pump; 5-RF generator; 6-plasmatron; 7-powder feed system; 8-gas feed system; 9-manometer; 10 - rate meter; 11, 12, 13inlet valve for the flow rate regulating; 14-air-admission valve.

None organic sediment, achieved by the SCWO process is put to powder feed system (7). Valves (11), (12), (13), (14) are closed, backing pump is switched on and by the reaching of 300 bars double-rotor (4) is switched on. Having prior decontamination powder under vacuum for 10 minutes at a pressure of up to $6 \mathrm{~Pa}$. Next the inlet valve (11) and (13) are opened and set the gas flow. After turning on the RF generator (5), the gas passing the inductor zone is being ionized. After generating the discharge the inlet valves (12) and (13) open and set the gas flow rate and the flow of powder from the powder feed system (7). Powder captured by the gas stream and fed into the discharge zone, and then into a glass-collection (2). Periodically vessel with powder was being mechanically shaken. After treatment, the RF generator (5) turns down, letting the atmospheric air through a valve (14).

Powder element composition determined before and after plasma treatment by a method of the XRF analysis on universal X-ray spectrometer SUR-02 "Renom FV".

\section{Results and Discussion}

\subsection{Extraction Path}

Solubility description of the investigated substances in supercritical carbon dioxide is carried out in the framework of the concepts presented in the study [1]:

$$
\frac{\partial \ln y_{k}}{\partial p}=\frac{V_{m}^{k}}{R T}-\frac{1}{p}-\frac{\partial \ln \varphi_{k}}{\partial p},
$$

Here $y_{k}-$ Mole fraction of solute substance $k$ in the solvent, $V_{m}^{k}$-molar volume of the substance, $p-$ System pressure, $\varphi_{k}$-Volatility coefficient.

Volatility coefficient of component $k$ at $T, V=$ Const:

$$
\ln \varphi_{k}=\int_{V_{M}}^{\infty}\left[\left(\frac{\partial n z}{\partial n_{k}}\right)_{T, V}-1\right] \frac{d V_{M}}{V_{M}}-\ln z,
$$

Here $n=\sum_{k} n_{k}$ - The total number of moles in the mixture, $\quad n_{k}$-moles number of component $k$, $V_{M}=V / n$-Molar volume of the mixture, $z-$ compressibility factor is determined from the corresponding state equation.

For the subsequent determination of the compressibility factor the equation of Peng-Robinson was chosen:

$$
\begin{gathered}
P=\frac{R T}{V_{M}-b}-\frac{a}{V_{M}^{2}+2 b V_{M}-b^{2}}, \\
z=\frac{P V_{M}}{R T},
\end{gathered}
$$

Here $a, b$-equation parameters, in the frames of a specific mixing law.

The following general form of ratios was elected:

$$
\begin{gathered}
a=\sum_{i, j} \sigma_{i, j} a_{i, j}\left(\frac{b}{b_{i, j}}\right)^{\beta_{i, j}} y_{i} y_{j}, \\
b=\sum_{i, j} x_{i, j} b_{i, j} \sqrt{y_{i} y_{j}}
\end{gathered}
$$

Here $a_{i, j}=a_{j, i}, b_{i, j}=b_{j, i}$ are some coefficients depending on the temperature and the critical parameters ( $T_{c r}$ and $P_{c r}$ ) of the mixture components, $\sigma_{i, j}=\sigma_{j, i}$, $\sigma_{i, i}=1, \quad \gamma_{i, j}=\gamma_{j, i}, \gamma_{i, i}=1, \quad \beta_{i, j}=\beta_{j, i}, \beta_{i, i}=1$-Binary interacttion coefficients, $y_{i}=n_{i} / n$-Mole fraction of the component $i$ in the complex mixture.

Calculation of binary interaction coefficients for the different mixing rules is based on the best rms approximation to the available experimental data on the basis of conditions:

$$
\min _{\sigma, \gamma, \beta} \sqrt{\frac{1}{n} \sum_{s=0}^{n}\left(\frac{\bar{y}_{k}^{s}-y_{k}\left(p_{s}\right)}{\bar{y}_{k}^{s}}\right)^{2}},
$$

Here $y_{k}\left(p_{s}\right)$ is determined from the equation of solubility (1) by substituting the corresponding values of $p_{s}$ and $\bar{y}_{k}^{s}$.

The results of the measurement of soluble components are shown in Figures 7-10. Solubility description performed using Peng-Robinson equation and the three binary interaction coefficients.

Table 1 shows the binary interaction coefficients $\left(\sigma_{i j}\right.$ $\left.\beta_{i, j} \gamma_{i, j}\right)$ and the mean square error $(\Delta)$ at different temperatures, obtained by the authors of this paper. 


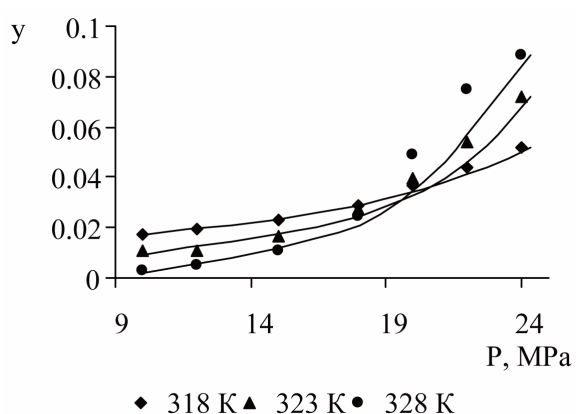

Figure 7. Metilfenilkarbinol solubility in supercritical $\mathrm{CO}_{2}$ on the results of experimental studies and descriptions.

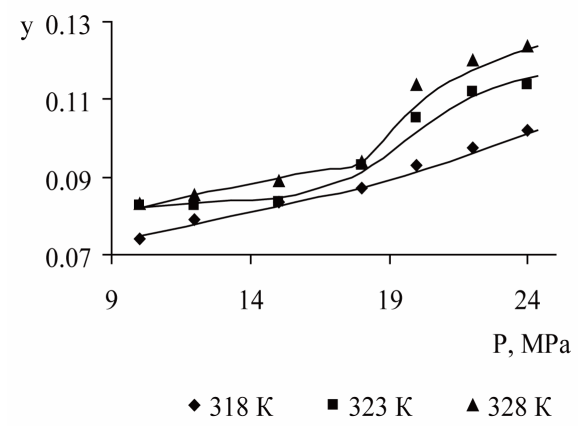

Figure 8. Acetophenone solubility in supercritical $\mathrm{CO}_{2}$ as a result of the pilot study and description.

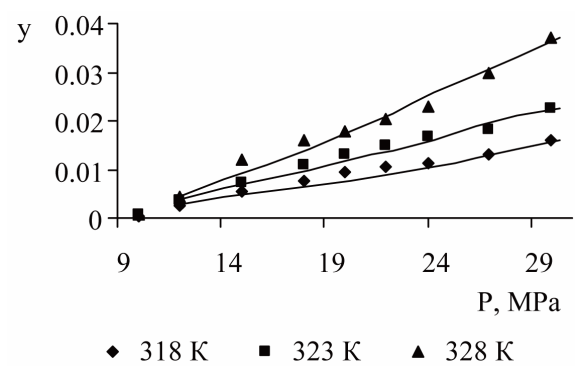

Figure 9. Propylene glycol solubility in supercritical $\mathrm{CO}_{2}$ as a result of the pilot study and description.

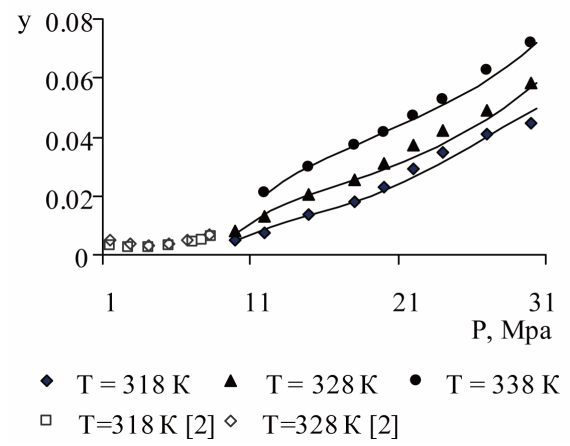

Figure 10. Ethyl benzene solubility in supercritical $\mathrm{CO}_{2}$ as a result of the pilot study and description.

Figure 10 presents data on the solubility of ethyl benzene in $\mathrm{SC}-\mathrm{CO}_{2}$, obtained by the authors of this work, as well as data on the solubility obtained on the basis of studies of equilibrium "vapor-liquid" system "ethylbenzene- $\mathrm{CO}_{2}$ " presented in [2]. There is a satisfactory agreement.

Problem of molybdenum separation, from an economic point of view, is more important than recovery of hydrocarbons, widely represented in the water flow. It is known that metal ions are virtually insoluble in $\mathrm{SC}-\mathrm{CO}_{2}$ [3], which led to the formation of an organ metallic complex based on molybdenum. As the ligand disodium edetate (EDTA) is used (in the literature under the names "chelating III" or "Trilon B"). Experimental results of solubility of the organ metallic complex based on molybdenum and EDTA are shown in Figure 11.

Table 1. Certain binary interaction coefficients and the.

\begin{tabular}{|c|c|c|c|c|c|}
\hline $\begin{array}{l}\text { The } \\
\text { component } \\
\text { in question }\end{array}$ & $\begin{array}{c}\text { Temperature } \\
\text { Experiment, } \\
\mathrm{K}\end{array}$ & $\sigma_{i, j}$ & $\beta_{i, j}$ & $\gamma_{i, j}$ & $\Delta$ \\
\hline $\begin{array}{l}\text { Metilfenilkarb } \\
\quad \text { inol }\end{array}$ & $T=318$ & 0.2425 & 0.6407 & $\begin{array}{c}4.81 \times \\
10^{-6}\end{array}$ & 0.02779 \\
\hline $\begin{array}{l}\text { Metilfenilkarb } \\
\text { inol }\end{array}$ & $T=323$ & 0.4716 & 1.2025 & 0.0000 & 0.11019 \\
\hline $\begin{array}{l}\text { Metilfenilkarb } \\
\text { inol }\end{array}$ & $T=328$ & 0.7836 & 1.0688 & 0.0000 & 0.1608 \\
\hline Acetophenone & $T=318$ & 1.7499 & 1.1878 & 1.3761 & 0.00852 \\
\hline Acetophenone & $T=323$ & 1.8438 & 1.2539 & 1.6210 & 0.01289 \\
\hline Acetophenone & $T=328$ & 1.6392 & 1.2528 & 1.6366 & 0.01041 \\
\hline Propylene & $T=318$ & 0.8409 & 0.1876 & 0.0000 & 0.11759 \\
\hline Propylene & $T=323$ & 1.2734 & $\begin{array}{c}6.2035 \times \\
10^{-5}\end{array}$ & 0.0449 & 0.07595 \\
\hline Propylene & $T=328$ & 1.2505 & 0.4184 & 0.0000 & 0.10251 \\
\hline Ethylbenzene & $T=318$ & 0.8994 & 1.1849 & 0.0000 & 0.07459 \\
\hline Ethylbenzene & $T=318$ & 0.5085 & 1.9452 & 0.000 & 0.07295 \\
\hline Ethylbenzene & $T=328$ & 0.4556 & 0.8528 & 0.0000 & 0.07208 \\
\hline Ethylbenzene & $T=328$ & 0.4556 & 0.8528 & 0.000 & 0.07208 \\
\hline Ethylbenzene & $T=333$ & 0.2629 & 0.9641 & 1.1639 & 0.01960 \\
\hline
\end{tabular}

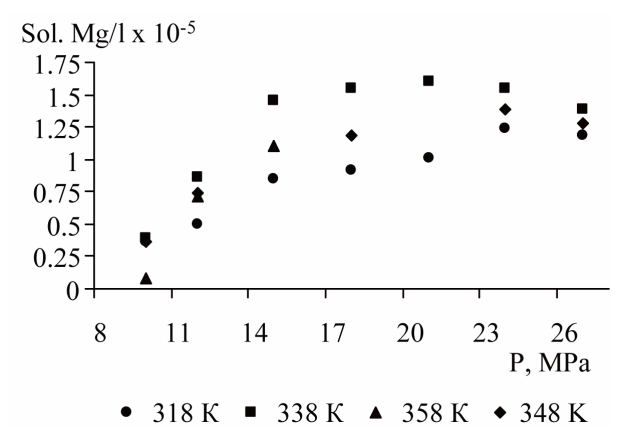

Figure 11. Solubility of the organ metallic complex based on molybdenum and EDTA in SC-CO . 
Theoretical basis of the extraction process, by the solubility research result of the target component in the proposed extractant, is added with characteristics of the supercritical fluid $\mathrm{CO}_{2}$ extraction process realized at $T=$ $318 \mathrm{~K}$ and pressures of $12 \mathrm{MPa}$ and $24 \mathrm{MPa}$.

At a pressure of $24 \mathrm{MPa}$ ligands were added in the water flow (waste) and obtained only one extract. Composition of samples is presented in Table 2.

Of the 94, 4 grams of waste at source of $12 \mathrm{MPa}$ was recovered 12.23 grams of the extract, the ratio of waste: extractant was 1:18. At $24 \mathrm{MPa}$ was obtained $7.42 \mathrm{~g}$ of the extract, the ratio of waste: extractant was 1:10.

The main components of the extract are phenol and MPC, due to their higher solubility in $\mathrm{SC}-\mathrm{CO}_{2}$ rather than in cases of ethylbenzene and propylene glycol. Negligible content of Acetophenone in the extract, primarily due to its low concentration in the water flow.

Analysis of the data presented in Table 2 shows that at a pressure of $12 \mathrm{MPa}$, phenol, and acetophenone methyllphenylcarbinol extracted, respectively, by $97 \%, 95 \%$, $90 \%$, whereas ethyl benzene and propylene glycol are removed only by $5 \%$ and $0.4 \%$. The recovery of molybdenum at $P=24 \mathrm{MPa}$ was $16 \%$.

Molybdenum containing an extract obtained from water runoff was tested as a catalyst for epoxidation. However its activity turned out to be lower in comparison with the industrially-produced catalyst (CMC). Exactly hydroperoxide conversion was only $68 \%$ (96\% in CMC) with a selectivity of $65 \%$ by weight ( $98 \%$ of $\mathrm{CMC})$.

\subsection{Supercritical Water Oxidation Method}

An important step in the removal of waste is investigated selection or precipitation of salts of molybdenum. Molybdenum represented a departure at a concentration of about $0.2 \%$ by weight (based on the pure metal). Isola-

Table 2. Composition of the water flow and $\mathrm{SC}-\mathrm{CO}_{2}$ extracts.

\begin{tabular}{ccccccc}
\hline \multirow{2}{*}{$\begin{array}{c}\text { Waste } \\
\text { components }\end{array}$} & $\begin{array}{c}\text { Original } \\
\text { departure }\end{array}$ & $\begin{array}{c}\text { The extract } \\
\text { obtained at } 12 \mathrm{MPa}\end{array}$ & \multicolumn{2}{c}{$\begin{array}{c}\text { The extract } \\
\text { obtained at } 24 \\
\text { MPa the ligand }\end{array}$} \\
\cline { 2 - 7 } Weight, g & $\%$ & Weight, g & $\%$ & Weight, g & $\%$ \\
\hline Ethylbenzene & 2,38 & 2.53 & 0.13 & 1.06 & 0.17 & 2.30 \\
Propylene & 11.5 & 12.20 & 0.07 & 0.57 & 0.02 & 0.30 \\
ACF & 0.7 & 0.74 & 0.63 & 5.15 & 0.64 & 8.56 \\
MPC & 6.99 & 7.40 & 6.62 & 54.14 & 3.71 & 50.01 \\
phenol & 3.23 & 3.42 & 3.14 & 25.68 & 1.63 & 22.03 \\
benzoic acid & 0.00 & 0.00 & 0.53 & 4.33 & 0.39 & 5.21 \\
molybdenum & 0.25 & 0.26 & 0 & 0 & 0.04 & 0.56 \\
other comp. & 69.3 & 73.45 & 1.11 & 9.07 & 0.82 & 11.00 \\
All in all & 94.4 & 100 & 12.23 & 100 & 7.42 & 100 \\
\hline
\end{tabular}

tion of molybdenum by precipitation in the form of molybdic acid or molybdenum three sulfide is difficult, on the one hand, the relatively low metal content in the solution, on the other hand, the presence of large quantities of organic and inorganic compounds, as well as the related group- $\mathrm{V}$ metals (chromium, iron, etc.), eluted from the walls of vehicles during the corrosion process.

To assess the influence of pressure and temperature on the oxidation of waste SCWO experiments on static method at different pressures and constant temperature, as well as various temperatures and constant pressure.

Waste spectrogram is shown in Figure 12 as the upper band, which has many peaks. The second band from the top corresponds to the product of the reaction SCWO (20\% concentration of the waste, $30 \% \mathrm{H}_{2} \mathrm{O}_{2}$, ratio of $1: 1$. Third band corresponds to distilled water. Actual coincidence of the second and third bands shows the oxidation of organic compounds contained in the waste.

Wastewater treatment was conducted on the periodic SCWO setup with $\mathrm{COD}=800,000 \mathrm{mg} \mathrm{O} /$ liter waste to $\mathrm{COD}=1880 \mathrm{mg}$. $\mathrm{O}_{2} /$ liter waste. Elemental analysis of dry residue after SCWO process, held on energy dispersive X-ray fluorescence SPECTROMETRY SUR-02 "Wren ejection", presented in Table 3.

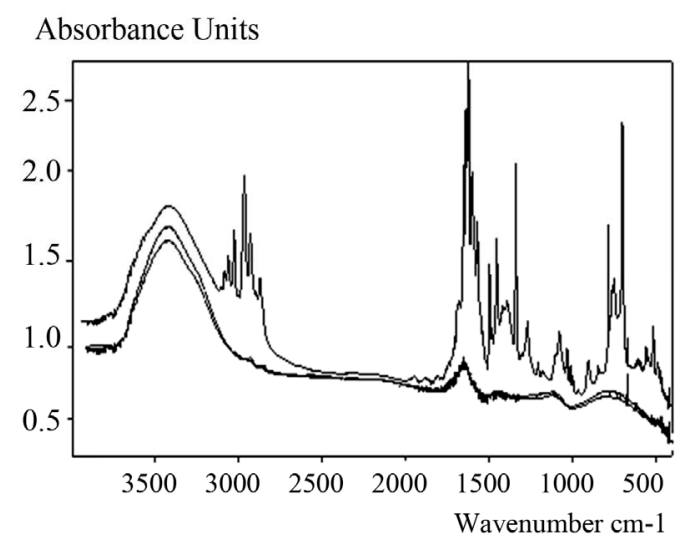

Figure 12. IR spectrogram of solid sediment.

Table 3. The content of metals found in the elements sediment.

\begin{tabular}{cc}
\hline Element & Mass \% \\
\hline $\mathrm{Ca}$ & 6.3 \\
$\mathrm{Cr}$ & 3.7 \\
$\mathrm{Mn}$ & 0.6 \\
$\mathrm{Fe}$ & 52.5 \\
$\mathrm{Ni}$ & 3.2 \\
$\mathrm{Cu}$ & 6.0 \\
$\mathrm{Zn}$ & 0.96 \\
$\mathbf{M o}$ & $\mathbf{2 4 . 8}$ \\
\hline
\end{tabular}


This spectrometer does not analyze sulphide and carbide sediments.

As the estimated efficacy parameter of oxidationchemical oxygen demand (dichromate method) was taken. The results of these experiments are shown in Figures 13-15.

As the graphs show, in general an increase in pressure and temperature promote oxidation of waste, however, despite the full-time amount of excess oxygen $(300,000$ filed $\mathrm{mg} \mathrm{O}_{2} / \mathrm{dm}^{3}$ For stoichiometric needs $190,000 \mathrm{mg}$ $\mathrm{O}_{2} / \mathrm{dm}^{3}$ ) complete oxidation occurs. The reason may be the presence of aromatic hydrocarbons in waste, in particular, phenol, the contents of which can be up to $6 \%$. If you have large amounts of aromatic hydrocarbons complete oxidation prevents the formation of tar from prepossession radical reaction between the aromatic fragments [4]. The same pressure plays a big role in the speed and ways of interaction of radicals.

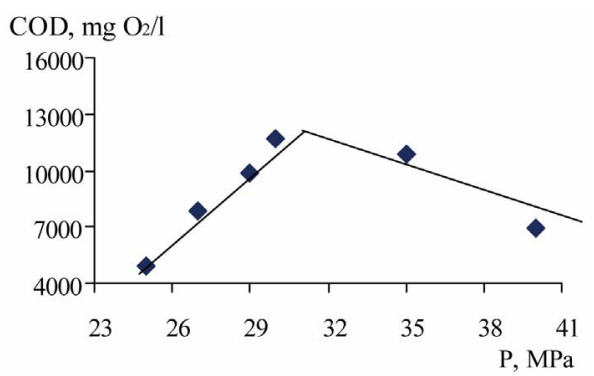

Figure 13. The dependence of the COD of the liquid phase after oxidation of undiluted waste at constant temperature $(T=663 \mathrm{~K})$.

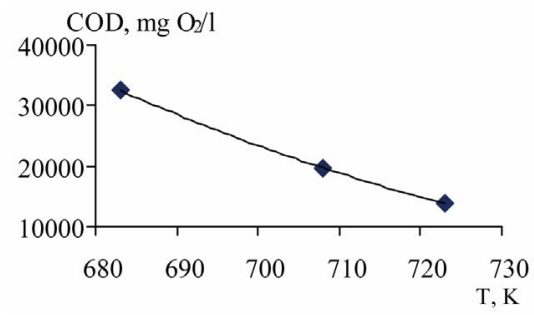

Figure 14. Dependence of COD of the liquid phase after oxidation of undiluted waste at constant pressure $(P=32$ MPa).

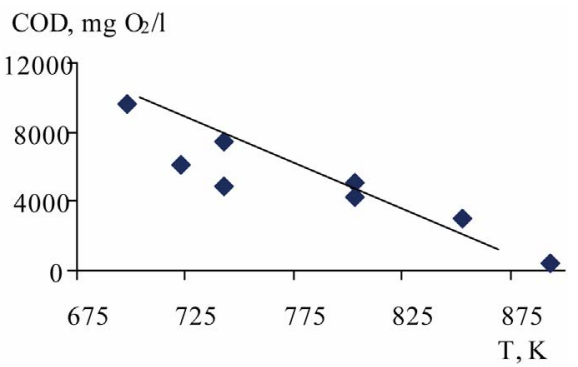

Figure 15. COD dependence on the temperature SCWO effluent in FTAs $=20 \%, P=300$ bar.
With increasing pressure, the rate of radical reactions between the aromatic fragments increases in connection with which the oxidation rate is significantly reduced. For complete oxidation of phenol and other aromatic hydrocarbons to a significant increase in temperature and decrease in the concentration of aromatic hydrocarbons in the waste.

COD dependence on the temperature SCWO effluent on a continuous flow setting is shown in Figure 15.

The experiments smallest $\mathrm{COD}=400 \mathrm{mg} \mathrm{O} /$ liter was obtained at $T=893 \mathrm{~K}, P=300$ bar (tolerance for process water $\mathrm{COD}=1000 \mathrm{mg} \mathrm{O}$ /liter).

As a result of the oxidation reaction at the bottom of the cell precipitate formed. Depending

On the process, the amount of sediment ranged from $10 \%-20 \%$ by weight of the loaded waste.

It was found that after the influence of plasma treatment maintenance of $\mathrm{Zn}$, Mo considerably increases; $\mathrm{Mn}$, $\mathrm{Cr}, \mathrm{Ni}, \mathrm{Fe}$ decreases (see Table 4). It is necessary to pay attention that maintenance of Mo after passing trough plasma increases in 1.7 times.

Explanation of the obtained results can be made according to a physical model [9]: Each object placed in plasma is charging negatively. However, when using a $\mathrm{RF}$ electromagnetic field besides the twin-layer (thickness of $10 \mu \mathrm{m}$ ) there is a Positive Charged Layer (PCL) around object. The potential concerning plasma reaches $100 \mathrm{~V}$. The reason is the lining of RF voltage on PCL, which is a plasmas diode.

In PCL low energy ions forms with about $30-100 \mathrm{eV}$ by energy and up to $25 \mathrm{~A} / \mathrm{m}^{2}$ by current density. When ions hit the surface they give the kinetic energy and energy of a recombination to material crystal matrix atoms. This energy is enough for decomposition of metal oxides and salts. While the molybdenum concentration in sediment increases because of its high density and infusibility.

\section{Findings}

The solubility study of water flow (waste epoxidation of olefins) components in $\mathrm{SC}-\mathrm{CO}_{2}$ was investigated in case to form a thermodynamic basis of the SCF extraction retrieval method. Low cost, dye-implemented process as applied to the aforementioned industrial effluents and analyzed compositions derived extracts. The results of this study suggest the possibility of a successful extrac-

Table 4. Element composition of powder after low pressure ICP treatment.

\begin{tabular}{ccccccccccc}
\hline Sample & $\mathrm{Ca}$ & $\mathrm{Cr}$ & $\mathrm{Mn}$ & $\mathrm{Fe}$ & $\mathrm{Ni}$ & $\mathrm{Cu}$ & $\mathrm{Zn}$ & $\mathrm{Mo}$ & $\mathrm{Ti}$ & $\mathrm{S}$ \\
\hline 1 & 6.3 & 3.7 & 0.6 & 52.5 & 3.2 & 6.0 & 1.4 & 24.8 & - & 0.1 \\
2 & 6.6 & 2.3 & 0.2 & 35.4 & 1.3 & 6.3 & 4.3 & 42.8 & 0.8 & - \\
\hline
\end{tabular}


tion of such components flow as methylphenylcarbinol (MPC), phenol, and acetophenone. At the same time, the problem of molybdenum extraction method is problematic because of the relatively low solubility of the organometallic complex at its base in $\mathrm{SC}-\mathrm{CO}_{2}$. Oxidation of waste in supercritical water has a significant advantage over the thermal treatment by reducing the amount of air emissions, improve the quality of clearance, possible and recycle water neutralized. With an appropriate composition of the waste heat can be used for internal exothermic production needs. At the same time for a more complete oxidation of the waste in a stoichiometric oxygen content to decrease the concentration of aromatic hydrocarbons, such as phenols, to prevent the formation of radicals. May decrease the concentration by dilution with water or waste and recycling (recycling oxidized water), as well as due to the removal of aromatic hydrocarbons from waste before it enters the reactor.

Dilution of waste is the simplest method for reducing the concentration of aromatic hydrocarbons, but it would require increasing the size of the reactor, power pumps, pipeline capacity. Removal of aromatic hydrocarbons by extraction with supercritical $\mathrm{CO}_{2}$ before entering the SCWO reactor-the most optimal method of preparation of raw material.

Metal salts, including molybdenum contained in the waste during SCWO into a safe and convenient form for later use.

The experiments have shown the possibility of implementing a two-step process spine recycling industrial waste production epoxidation of propylene to isolate valuable hydrocarbons extras action supercritical $\mathrm{CO}_{2}$ followed by SCWO for inorganic compounds and water suitable for reuse in manufacturing. The studies were conducted with the support of the promotion of small enterprises in scientific and technical sphere (contract No. 5856 from 31.03.08). The results of research are protected by patents of the Russian Federation $[10,11]$, the patent for utility model [12].

\section{REFERENCES}

[1] I. Ashour, R. Almehaideb, S.-E. Fateen and G. Aly, "Representation of Solid-Supercritical Phase Equilibria Using
Cubic Equation of State," Fluid Phase Equilibria, Vol. 167, No. 1, 2000, pp. 41-61. doi:10.1016/S0378-3812(99)00314-3

[2] C.-S. Tan, S.-J. Yarn and J.-H. Hau. "Vapor-Liquid Equilibria for the System Carbon Dioxide-Etyldenzene and Carbon Dioxide-Styrene", Journal of Chemical \& Engineering Data, Vol. 36, No. 1, 1991, pp. 23-25. doi: $10.1021 / \mathrm{je} 00001 \mathrm{a} 007$

[3] F. M. Gumerov, A. N. Sabirzyanov and G. I. Gumerova, "Sub- and Supercritical Fluids in Polymers Processes," Kazan FEN, 2000, pp. 328.

[4] A. A. Vostrikov, D. U. Dubov and S. A. Psarov. "Thermo Explosion Effects in SC Water," JTV, Vol. 27, No. 20, 2001, pp. 7-13.

[5] S. V. Dresvin, "Osnovy Teorii I Rascheta Vysokochastotnykh Plazmotronov (Fundamentals of Theory and Calculation of Radiofrequency Plasma Generators)," Energoatomizdat, Leningrad, 1991.

[6] I. Sh. Abdullin, V. S. Zheltukhin, I. R. Sagbiev and M. F. Shaekhov, "Modifikatsiya Nanosloev v Vysokochastotnoi Plazme Ponizhennogo Davleniya (Modification of Nanolayers in Radiofrequency Plasma of Low Pressure)," KSTU, Kazan, 2007.

[7] I. Sh. Abdullin, A. N. Bykanov, I. G. Gafarov, O. E. Ibragimov and R. F. Sharafeev, "Spectral Diagnostics of Inductively Coupled RF Discharge Plasma," High Energy Chemistry, Vol. 46, No. 4, 2012, pp. 271-275. doi:10.1134/S0018143912040029

[8] I. R. Sagbiev, I. Sh. Abdullin and R. F. Sharafeev, "Regeneraciya Aktivnogo Nanosloya Otrabotannogo Alumohromovogo Katalizatora v RF Plasma Ponizhennogo Davleniya (Active Nonalayer Regeneration Finished by Aluminium-Chrome Catalyst in Low Pressure RF Plasma)," Perspective Materials, No. 5, 2007, pp. 93-96.

[9] I. Sh. Abdullin and M. F. Shaekhov, "The Radio-Frequency Discharge of the Lowered Pressure during Processing Porous," Vestnik KSTU, No. 1, 2002, pp. 75-78.

[10] "Method of Disposal of Waste of Catalytic Olefin Epoxidation," Patent No. 2393152, 2010.

[11] "Method of Extraction of Molybdenum Products Catalytic Epoxidation of Olefins with Organic Hydroperoxides," Patent No. 2367609, 2009.

[12] Method of Disposal of Waste Containing Hydrocarbons with Simultaneous Precipitation of Dissolved Metal Salts and Device for Its Implementation: The application for the Invention of the Russian Federation, No. 2011141657, 2011. 